\title{
Operational instrument for primary assessment of intrinsic quality of open educational resources
}

Ciprian Baciu, Mușata Bocoș, Daniel Andronache, Victor Bocoṣ 


\title{
Operational instrument for primary assessment of intrinsic quality of open educational resources
}

\author{
Ciprian Baciu ${ }^{a^{*}}$, Mușata Bocoș ${ }^{b^{*}}$, Daniel Andronache ${ }^{\mathrm{c}^{*}}$, Victor Bocoș $^{\mathrm{d}^{*}}$ \\ a,b,c Faculty of Psychology and Educational Sciences, Babeş-Bolyai University, 7 Sindicatelor Street, 400015, Cluj-Napoca, Romania \\ ${ }^{d}$ Faculty of Environmental Science and Engineering, Babeş-Bolyai University, 30 Fântânele Street, 400294, Cluj-Napoca, Romania \\ *Corresponding author: ciprian.baciu@ubbcluj.ro,musata.bocos@ubbcluj.ro,daniel.andronache@ubbcluj.ro,victor.bocos@ubbcluj.ro
}

\section{Abstract}

Keywords: web educational resources, open educational resources, evaluation of web educational resources
The open educational resources (OER) are those resources which make reference to categories of educational materials which are in the public domain or which are available to readers by open licenses, so for which the access is free. A few examples of OER are school textbooks, curriculum, syllabi, course supports, audio-video resources.

Given the multitude, diversity and complexity of OER, and the fact that many times there are no objective and thorough conventions and regulations of selection, access, filtration and evaluation of them, specific selection and evaluation strategies must be identified.

This article is guided by the following questions:

a) What are the intrinsic qualities that the web educational resources should have?

b) How could we support with instruments the persons interested in the selection, study, and evaluation of web educational resources?

Starting from these questions, we offer an operational instrument/checklist of evaluation of the intrinsic quality of OER, and a series of landmarks for the primary evaluation of OER, as a component of the primary evaluation of e-resources.

\section{Zusammenfasung}

\section{Schlüsselworte:}

Web-

Bildungsressourcen,

Offene

Bildungsressourcen,

Bewertung von Web-

Bildungsressourcen
Offene Bildungsressourcen sind frei zugängliche Lernmittel, die gemeinfrei sind oder auf Basis freier Lizenzen die Verwendung erlauben. Beispiele offener Bildungsressourcen sind: Schulbücher, Bildungsinhalte, Lehrpläne, Lernmittel, Audio- und Videoressourcen.

Wegen der Vielzahl, Vielfalt und Komplexität der offenen Bildungsressourcen sowie aufgrund dessen, dass keine gegenständliche und präzise Auswahl-, Zugangs-, Filtrier- und Auswertungsregelungen dieser Ressourcen zur Verfügung stehen, kommt die Ermittlung spezifischer Auswahl- und Beurteilungsstrategien infrage.

Folgende Aufgabenstellung ist Grundlage dieser Arbeit:

a) Welche wesentliche Qualitäten sollten Web-Bildungsressourcen aufweisen?

b) Wie könnte das Instrument die Interessenten in Auswahl, Studium und Bewertung von Web-Bildungsressourcen unterstützen?

Ausgehend von dieser Aufgabenstellung, stellen wir ein operatives Instrument/ eine Kontrolliste zur Qualitatsbeurteilung von offenenen Bildungsressourcen sowie Meilensteine zur Grundbeurteilung von offenen Bildungsresoourcen, als wesentlicher Bestandteil der Grundbeurteilung von E-Ressourcen zur Verfügung.

\section{Argumentation of theme relevance}

The unprecedented technological and socio-economic changes which characterized the last years, the whole rhetoric, and the real movement to the knowledge-based and learning-based economy and society, as well as the perspective, overturns regarding the production and distribution of knowledge in contemporary society brought the educational systems to new series of complex problems and challenges. For example, the evaluation of the Strategic Framework "Education and training 2020" (http://ec.europa.eu/education/policy/strategicframework_en) (ET 2020) for the European cooperation in education and professional training highlighted a priority field: the opened and innovating education systems, including by the maximal valorization of digital age.

Our work represents a pleading in favor of the idea that in a digital age, the change, development and general progress are inseparably connected to the digital field and the technological tools. It changes the frames, contexts, and pace of macrosocial development, which assures the successive passage from information society to the society of knowledge, to the learning society and to the digital society, the affirmation of digital field in the context of globalization phenomenon. 
We live in the knowledge society, a society founded on knowledge and its dissemination, by taking into account the specific dynamism and the necessity of its prospective orientation. The knowledge society was gradually configured, as a result of information explosion, generator of a huge volume of scientific acquisitions; practically, knowledge means the accumulation of data and information, actions of information and dissemination of resources and knowledge. In other words, knowledge society is founded on information society, which crystallized after the computerization due to the realization of industrial revolutions which led to the development of NICT (New Information and Communication Technologies), automation and robotics. Thus, information society represents the foundation of the knowledge society. The latter generates knowledge and organizes it by transformation, processing, and articulation of information in knowledge resources. They become common, universal assets from which all the society members can benefit with the purpose of assuring the general human progress. As part of the knowledge society, the information society represents a new stage of human evolution, a new lifestyle, superior in quality, which involves the intensive use of information in all the spheres of activity and human existence, by promoting the opening and democratization of access to information. Thus, we consecrated the term Open Educational Resources (OER), which was defined in specialized literature in several ways to which we will refer below.

Before defining OER, we propose to offer our own definition of educational resources and open educational resources, by valorising the definition of the term "resource", from the field of economic sciences and connecting it with definitions from the education field: education, educational goals, educational resources (see the taxonomy offered by Bocoș, 2017).

Thus, in our vision, the educational resources represent the totality of material, human, financial, procedural, instrumental and time elements which can be attracted/made/elaborated and used for instructive educational purposes, in view of forming and developing the intellectual, moral or physical traits of students, according to the educational goals pursued.

A pedagogic analysis of educational resources involves the clarification of some issues such as: establishing the categories of resources involved in the educational process; estimation of the weight of each category; identification of specific teaching potential; establishing the methodical requirements in use etc., compared to the teaching objectives pursued. A taxonomy of educational resources which envisages the epistemological criterion and the specific contribution to the structure of instructive educational activity distinguishes the following five large categories: human resources, material resources, financial resources, procedural resources and time resources (Bocoş, 2017).

\section{Material resources related to the Internet}

We propose below to focus on a significant component of material resources, respectively on those categories of specific resources related to the Internet: Internet resource, digital educational resources, open educational resources (OER).

\subsection{Internet Resource}

The term Internet is indispensable in the information society, it practically became an omnipresent resource. In order to try to configure the specificity of this resource in the educational field, we reiterate the following work premises regarding the technical and material perspective of analysis:

a) The Internet represents an autonomous educational resource similar to financial, human, procedural resources etc. The existence and use of the Internet are closed conditioned by the existence of equipment (computers, smartphones, tablets, routers, servers etc.).

b) The Internet is a resource which offers us a virtual space which allows for carrying out online educational activities, with the valorization of facilities provided databases, online platforms, software, open educational resources etc. Therefore, it is justified to include the Internet in the material resources, the virtual space can be seen as an extension of the physical school space in cyberspace.

By completing this technical and material perspective with the curricular perspective, we offer the following educational developments:

a) From an architectural point of view, respectively the physical components which form the Internet (a huge network of computers, of world scope), the Internet represents the means of education which offers a communication environment as support for carrying out instructive educational activities. A relevant educational activity specific to this environment is the dissemination of 
digital teaching materials (textbooks in digital format, videos, software etc.). These materials are components of educational means, respectively educational resources which can be used for multiple purposes: information, study, problem resolution, experimentation, learning, application of acquisitions, dissemination of information etc.

b) From the point of view of dissemination of resources, the Internet is the component of material resources which offers the virtual educational space necessary for the carrying out of the online instructive educational process, the online teaching, learning and evaluation processes.

In conclusion, from a pedagogic perspective, the Internet has a dual status, being at the same time a means of education and communication environment/ virtual educational space. That is why, we could say that the Internet represents more than what its classical definition contains - the international network of computers formed by the interconnection of local and global networks, designed to facilitate the exchange of data and information in various fields (DEX, 2009). By customizing this definition for the educational field, we can say that the Internet represents the material educational resource and means of education formed by the world information network which offers a virtual communication environment/ virtual space necessary for the design/ elaboration, study, storage, dissemination of materials and digital learning resources, exchange of data and information, carrying out of educational processes.

\subsection{Digital Educational Resources}

The digital educational resources represent the assembly of teaching materials drawn up in digital format (graphic images, photographs, animations, audio and video files, games, software etc.) which the educational agents use in instructive educational processes, for achieving the preestablished educational objectives.

The use on a wide scale of digital educational resources is possible because of development of Information and Communication Technology (ICT), which offers a variety of instruments that can open up new possibilities in the classrooms. They can help in particular to differentiate and customize training, depending on the educational needs of each student and they can also offer them crucial digital competences, necessary in our knowledge-based economy (Negruț \& Arsith, 2013, Eurydice, 2011).
The major characteristic of digital educational resources is that they condense processed and structured information, which helps the students develop mental representations by a combination of multimedia elements: text, image, audio and video presentations, films, elements of virtual and augmented reality, for the purpose of efficient presentation of information. Digital educational resources can include digitalized contents and sequences of educational activities (Eady \& Lockyer, 2013, p. 71).

\subsection{Open Educational Resources (OER)}

\subsubsection{The notion of open educational resource}

The term Open Educational Resources (OER) refers to educational materials for which the access is free and free of charge; this term was adopted in UNESCO Forum in 2002, following the analysis of the Open Courseware projects impact in higher education.

According to UNESCO, open educational resources (OER) are those resources which make reference to categories of educational materials which are of public domain or which are made available to readers by open licenses. These open resources give all those interested the opportunity to access them, copy, use, adjust and transmit them legally and free of charge. In the composition of open educational resources, we can include the school textbooks, curriculum, syllabuses, course supports, homework, tests, projects, audio-video resources and resources based on animation techniques (UNESCO, 2002 apud Wiley, 2007, Hylén, 2006).

From a technical point of view, those which assure access to these resources by their distribution at world level. Thus, the educators and educable children have the opportunity to identify, take up, change and exchange online resources, depending on own educational needs, for the purpose of reaching the educational goals. Thus, the educable children will form competencies which allow them efficient social and professional insertion and the active participation in knowledge-based society.

From teaching perspective, open educational resources favour the active, interactive, heuristic and experiential learning, facilitate interpersonal communication, enhance the freedom of expression, contribute to the mediation of learning activity, to a better illustration and structuring of contents depending on the study pace of each educable child, assure an efficient management of contents, develop the comprehension capacity by undertaking the responsibility regarding what is learned, how is learned and 
when is learned, and by focusing the educational processes on the learning subject.

The open and flexible nature of OER contributes to the generation of a major change by realization of adequate and accessible learning systems regardless of the age of educable children, their financial possibilities, the space and time coordinates, by providing them with access to a multitude of instructive educational opportunities. Also, depending on the way in which these resources are licensed, the users can contribute to their updating or they can generate new OER both online and offline.

\subsubsection{Argumentation of the necessity of OER selection and evaluation strategies}

The exponential amplification of the number of educational resources of different kinds, their existence in the virtual space without the individual or institutional assumption of their quality represents a critical problem. For example, we mention the following problematic situations:

- most websites do not offer data about the author/editor or do not include sufficient data to check/ evaluate the quality of content of information provided;

- some users do not know how to search efficiently on the Internet;

- some users do not know how to evaluate objectively the resources found;

- there are web pages in which persons who do not have expertise speak with determination and authority about complex research themes;

- practically anyone can make and publish a website, can post information from/in any field, including false information, which was noticed by the UNESCO Report from Paris: "according to estimates, half of the information circulating on the Internet is false or inaccurate" (UNESCO, 2005, p. 47). Also, according to Gartner (2018), it is predicted that by 2022 more than $50 \%$ of the population of economically developed countries will consume more false information than true information;

- unlike the similar information found in the printed resources - books, articles in magazines (or radio/ television shows) which go through a process of analysis and filtration, such as editing and peer review, most of information on World Wide Web is published without going through this process, being non-filtered information; as they are not subject of regulatory measures, this date cannot be always accepted as real and true information and must be evaluated carefully before being included in the teaching-learning-evaluation or research activity.

Thus, the information which is in the virtual space, taken as such, in raw state, is just the basic material, which has the potential to lead to the generation of knowledge. The transformation of information into knowledge is only possible after a process of selection, evaluation, analysis, reflection, and processing.

Under these conditions, as OER and their forms of presentation multiply and diversify, the concerns for identification of strategies of selection, change, adjustment, valorization and evaluation of them in educational activities are justified and necessary. In view of configuring these strategies (Conole \& Ehlers, 2010, Caswell et al. 2008), we will envisage teaching variables such as: the age of educable children, their digital competences, the educational goals pursued, the specificity of study subject and its educational dominance, specificity of curricular contents circulated, teaching strategies used, characteristics of specific educational backgrounds, the complexity degree of educational activities.

\section{Own contributions to the selection and use of OER}

In order to offer operational support to the users of OER resources, we propose to answer the following general critical questions related to the selection and use of Web educational resources:

a) What are the intrinsic qualities that the web educational resources should have?

b) How could we support instrumentally the persons interested in the selection, study, and evaluation of web educational resources? In the attempt to answer these questions, by valorizing the specialized bibliography, we conclude that there are eight criteria involved in the selection and evaluation of web resources:

1. "Professional prestige of the author" criterion

2. "Accuracy" criterion

3. "Objectivity" criterion

4. "Updating" criterion 
5. "Informative potential" criterion

6. "Audience" criterion

7. "Design" criterion

8. "Accessibility, Navigability and Costs" criterion.
Between the eight criteria for selection, study and evaluation of OER there are intercorrelations and interdependences, which can be highlighted under the form of a rosette formed by eight connected petals, as you can see in Figure no. 1:

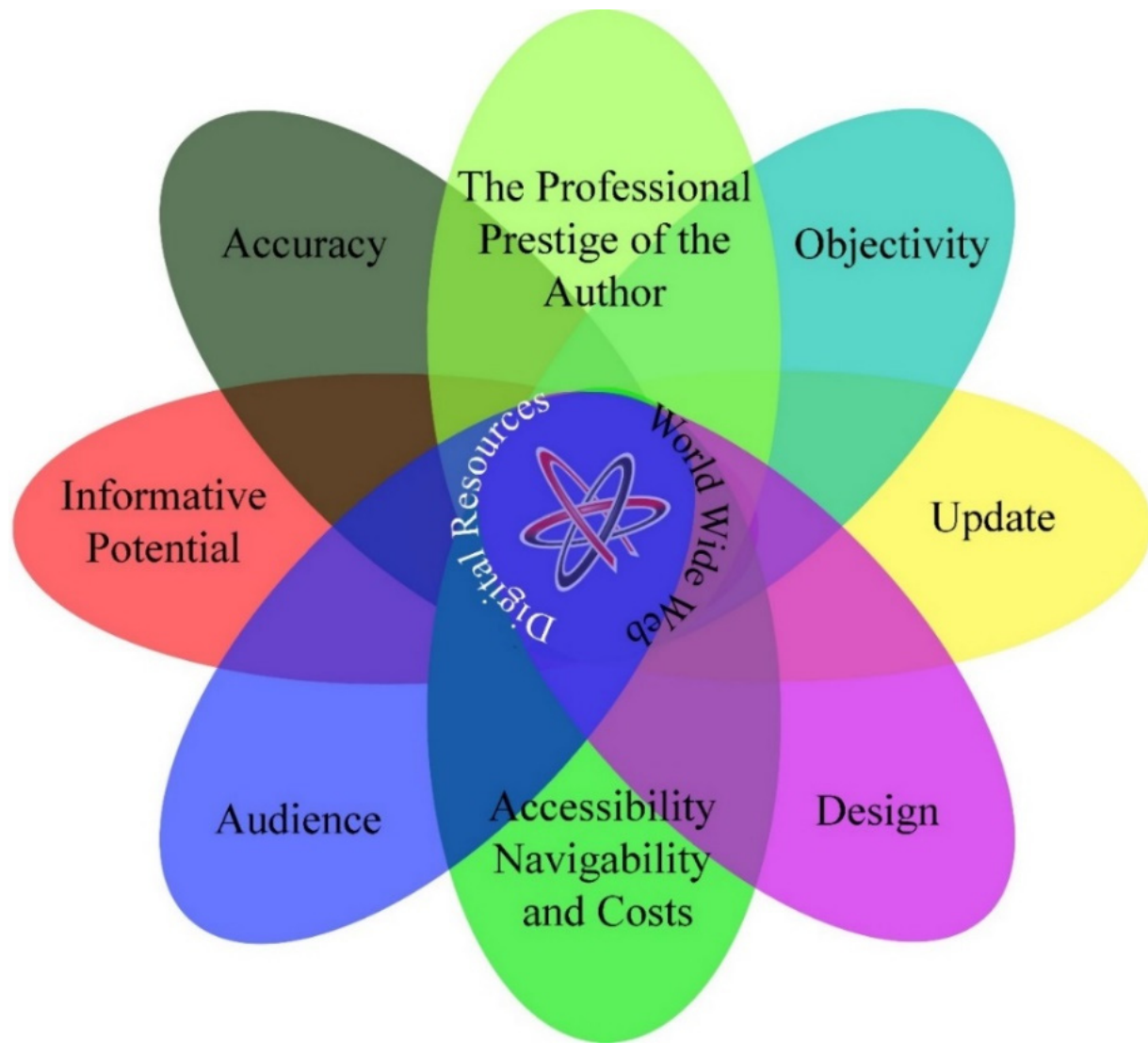

Figure no. 1. Rosette of selection and evaluation criteria of $O E R$

To continue our step of proposing strategies for selection and evaluation of OER, we propose an operational instrument for evaluation of intrinsic quality of these resources, data, and information of a web resource. This instrument represents a checklist which can guide the evaluation process. From a structural point of view, this checklist is formed by a series of intercorrelated dimensions, to which correspond operational indicators that quantify the OER features, easy to apply by the users (Table no. 1):

Table no. 1. Checklist - instrument for evaluation of intrinsic quality of OER

No. Dimensions of web resources analysis

"Professional prestige of the author"
Dimension
(PP)

\section{Operational indicators for quantification of dimension}

YES/NO

Is the name of author specified in the page?

Is the author qualified to write about that subject?

Does the Web document you read offer biographic information, including the position of the author, institutional affiliation and address?

Is there in the page contact information, at least a name and email address? 
If it is a website, is there the page "About"?

Is there on the page a link which redirects you to the home page? If this link exists, when you access it, does it redirect you to the page of an institution or to the personal page of a user?

Check the domain of website/ page where the document is. To which type of institution does the domain of web address indicate: .edu, .gov, .org, .com etc. - that this address belongs? As basic rule, the domains .gov, .mil and .edu are reliable and offer accurate information, the chances that the information on these websites is reliable are very high, they are checked before they get to the wide audience.

If it is the official website of an institution or organization, is there on the page the logo or other data which show that this document is part of the official website of an academic or scientific institution? Does it make reference to copyright? Is it an organization recognized in the field which you want to study?

In what country does the geographic domain show that that page is? (.ro, .fr, .ca, .uk, .au, .it etc).

If it is research, are the collected data included and is there explanation of research method(s) used for the collection and interpretation of data?

If facts and numbers are presented, are there quoted sources so that they can be checked in another article or in another printed book? If there are quotations or statements, can you check them by other means? Can you check the information provided?

If there are statistical data under the form of diagrams and/ or charts, are they clearly named and easy to read? Is the information in line with other pieces of information published on the same theme?

Is the methodology presented in document adequate to the research subject and does it allow that the study is repeated for checking purposes?

Is the document based on other sources which are listed in the bibliography (or does it include links to the specific documents)?

If a magazine was converted from the publication format on paper to the publication format online (web), is the web version the same as the printed edition, does it offer the same content?

"Accuracy" Dimension

(A1)
Is there offered information about peer-review?

Are there in document grammar mistakes, spelling or typing mistakes?

Are there links to other sources to check the statements from the document? To what sources does the link redirect?

If links to other sources are offered, are there links which do not work?

What institution (university, research institute, government, company etc.) validates this kind of information?

Objectivity refers to the bias/ discrimination in relating the information. Thus, you have to pay a special attention to the objectives of the author and the purpose of the website, by taking into account: 


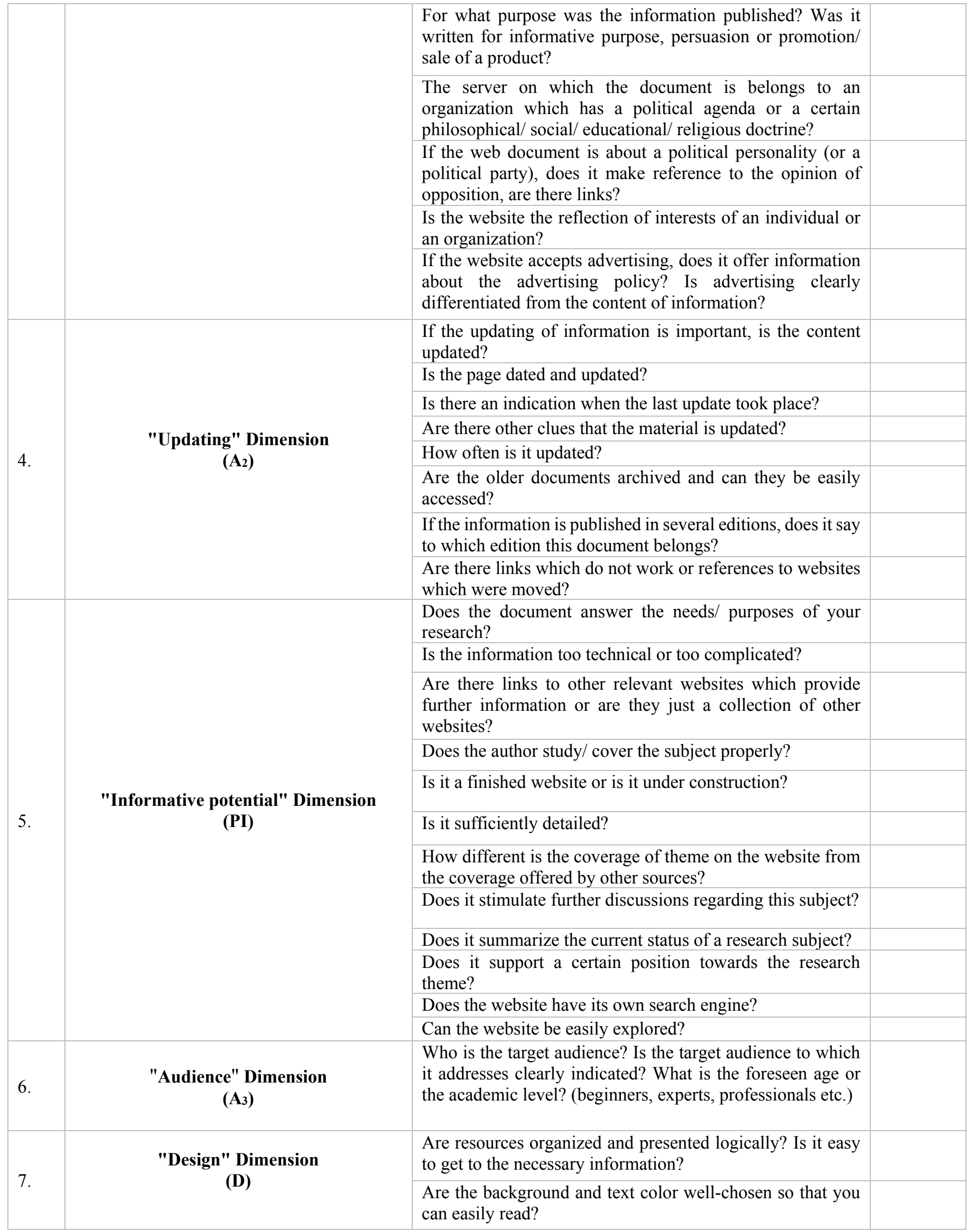




\begin{tabular}{|c|c|c|}
\hline & & $\begin{array}{l}\text { What is the quality of images? Is the graphic clear and } \\
\text { representative? Is the graphic functional or decorative? }\end{array}$ \\
\hline & & Is the graphic too complex, which leads to a slow loading? \\
\hline & & $\begin{array}{l}\text { Do these images help explore the resources or do they } \\
\text { distract your attention from the content? }\end{array}$ \\
\hline & & $\begin{array}{l}\text { Does the website have a design which allows the disabled } \\
\text { persons to surf, understand and interact with the web pages } \\
\text { efficiently? }\end{array}$ \\
\hline & & Is the website available consistently? \\
\hline & & Does it have a fast response time? \\
\hline & "Accessibility, Navigability and Costs" & Does it have an alternative based on the text? \\
\hline 8. & $\begin{array}{c}\text { Dimension } \\
\left(\mathbf{A}_{4}\right)\end{array}$ & $\begin{array}{l}\text { Does it require you to be registered with username and } \\
\text { password in order to have access to information? }\end{array}$ \\
\hline & & $\begin{array}{l}\text { Is the website open to anyone or is the access to some } \\
\text { sections charged with a fee? }\end{array}$ \\
\hline & & $\begin{array}{l}\text { Do the non-registered users have access to a part of the } \\
\text { website? }\end{array}$ \\
\hline & & $\begin{array}{l}\text { If the information is offered in another language, is it an } \\
\text { accurate translation? }\end{array}$ \\
\hline
\end{tabular}

By performing a deeper study of specialized bibliography, it seems that the most relevant criterion in the evaluation of OER is the professional prestige of the author of web sources. The professional prestige of the author is his/ her own personal construction, a continuous construction, based on active and interactive involvement in design, experimenting, and validation of web resources, in the acquisition of expertise in this field. Such a prestige is gradually acquired, by successive accumulations, which equip the author of web resources from cognitive, affective, attitudinal and social perspectives. Practically, the professional prestige of the author represents the value and consideration which the author holds in the social, professional, academic, school, cultural community etc., as a result of distinction, qualities and competencies declared. Thus, the author's prestige represents the vectorial component of the quality of web resources. Thus, in the determination of the quality of web resources (CR) in mathematical language, the professional prestige of the author (PP) occupies a privileged position, as can be seen in the mathematical equation below:

$$
C R=P P+\frac{A_{1}+A_{2}+A_{3}+A_{4}+O+P I+D}{7}
$$

Beyond the mathematical meanings, this mathematical equation suggests the complexity of the evaluation process of web resources. For an objective evaluation, we propose the staging of this process in two large evaluation sequences:

1) Primary evaluation

2) Complex evaluation.

In this article we are interested in the primary evaluation of OER, as component of primary evaluation of e-resources, along with the primary evaluation of web sources and the primary evaluation of e-resources protected by copyright - Figure no. 2, in which we highlighted the privileged status of the author's prestige in the evaluation process: 


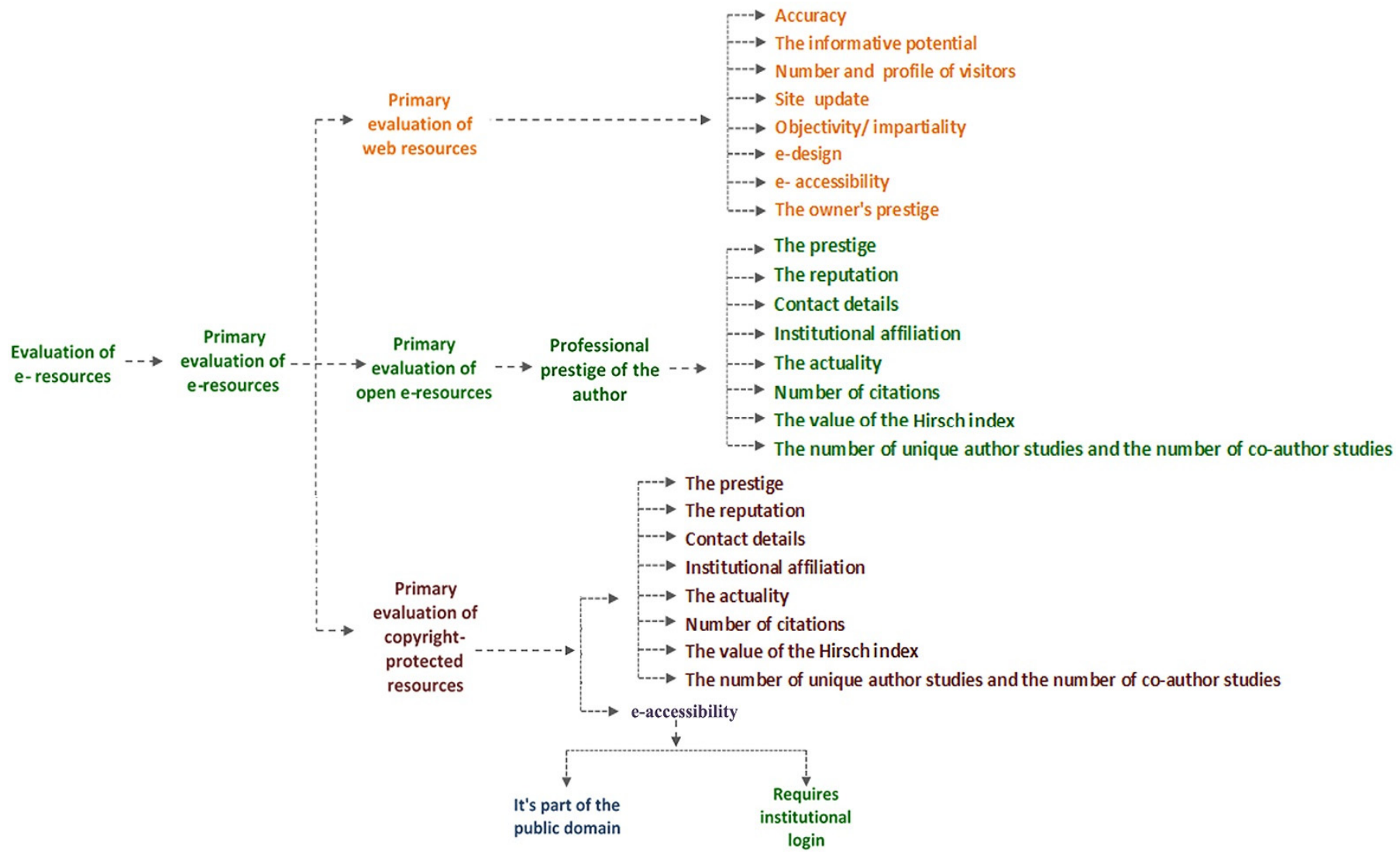

Figure no. 2. Status of the author's prestige in the evaluation process

\section{Conclusions}

Considering the multitude and diversity of web resources, and their forms of presentation, we ask the following critical questions: "What are the intrinsic qualities that the web educational resources should have?", "How could we support instrumentally the practitioners in the selection of web educational resources?". In the attempt to answer these two questions, we offered in this article a checklist, which can be valorized as an operational tool for evaluation of the intrinsic quality of web educational resources. We also elaborated a mathematical expression for the quality of web educational resources, an expression which valorizes the dimension "Professional Prestige of the author of web educational resources", a dimension which, in our vision, is central and referential.

\section{Authors note:}

Ciprian Baciu is Assistant Professor in the Department of Educational Sciences, Faculty of Psychology and
Education Sciences, Babeş-Bolyai University, Ph.D. in Education Sciences. His research is in the field of ICT, more precisely focused on e-teaching and e-learning.

Mușata Bocoş is University Professor and Ph.D. Coordinator at the Faculty of Psychology and Sciences of Education (Babeș-Bolyai University, Cluj-Napoca, Romania). She has obtained a Ph.D. in Educational Sciences in 1997 at Babeș-Bolyai University. Her research interests are reflected in a series of studies and articles published in important national and international journals. Her teaching activity covers several domains such as the theory and methodology of curriculum, general didactics, and educational research.

Daniel Andronache, Ph.D., is an Assistant Professor at the Department of Educational Sciences, Babeș-Bolyai University, Cluj-Napoca, Romania. He is graduate in Pedagogy (since 2008), master's degree in School Counseling (since 2010) and Ph.D. in educational sciences (since 2013). He made a research internship at the University of Vienna and in 2014 he received a Research Fellowship in educational sciences at Babeș- 
Bolyai University. Daniel Andronache' main fields of interest include: curriculum design, competence-based curriculum, systemic pedagogy, and teacher training.

Victor Bocoș is an Associate Professor at the Faculty of Environmental Science and Engineering, Babeș-Bolyai University, Cluj-Napoca, Romania. He holds a Ph.D. in Chemistry at Babeș-Bolyai University, since 2000. His principal research interests are related to trace detection of chemicals using advanced analytical techniques based on atmospheric pressure ionization of chemicals, such as ion mobility spectrometry. Additional research interest in neuroscience and education science. Teaching activity is focused onto inter-disciplinary fields, such as trace detection of chemicals and the application of advanced detection technologies for population protection.

\section{References}

Bocoş, M-D. (2017). Didactica disciplinelor pedagogice. Un cadru constructivist, ediţia a IV-a revizuită. Pitești: Editura Paralela 45.

Caswell, T., Henson, S., Jenson, M., \& Wiley, D. (2008). Open Educational Resources: Enabling Universal Education. International Review of Research in Open and Distance Learning, 9/1.

Conole, G.C., Ehlers, U.D. (2010). Open Educational Practices: Unleashing the power of OER. Paper presented to UNESCO Workshop on OER in Windhoek, Namibia.

DEX (2009). Dicționarul explicativ al limbii române, ediția a II-a, revăzută și adăugită. București: Editura Univers Enciclopedic, Academia Română.

Eady, M.J. \& Lockyer, L. (2013). Learning to Teach in the Primary School. Tools for learning: technology and teaching strategies. Queensland University of Technology, Australia.

Hylén, J. (2006). Open Educational Resources: Opportunities and Challenges. OECD's Centre for Educational Research and Innovation. Paris, France.

Negruț, V., Arsith, M. (2013). Proiectarea şi implementarea curriculumului centrat pe competenţe, Călinești: Editura Delta Cart Educaţional.

Strategic Framework "Education and training 2020" (ET 2020). http://ec.europa.eu/education/policy/strategicframework_en.
Wiley, D. (2007). On the Sustainability of Open Educational Resource Initiatives in Higher Education. Paris: OECD, Centre for Educational Research and Innovation.

UNESCO (2005). Towards knowledge societies, United Nations Educational, Scientific, and Cultural Organization (UNESCO) World Report. Paris, France: UNESCO Publishing.

UNESCO (2009). Open educational resources: conversations in cyberspace. D'Antoni, S. \& Savage, C., (Eds). Paris: UNESCO.

\section{Internet resources}

http://guides.library.cornell.edu/c.php?g=32334\&p=203767 http://libguides.southmountaincc.edu/CRAPtest http://mitiq.mit.edu/iciq/documents/iq\%20conference $\% 20200$ 4/papers/websitequalityassessmentcriteria.pdf http://www.ala.org/rusa/sections/history/resources/primarysou rces/evaluating http://www.pages.drexel.edu/ dea22/print.html https://academicguides.waldenu.edu/library/evaluating/websit

es

https:/guides.library.jhu.edu/evaluate/internet-resources https://libguides.asu.edu/c.php?g=264095\&p=1763442 https://libguides.colostate.edu/howtodo/evaluatewebpage https://libguides.libraries.wsu.edu/c.php?g=294158\&p=19596 04

https://libguides.uta.edu/researchprocess/sources https://library.elmhurst.edu/c.php?g=294877\&p=1964895 https://library.uaf.edu/ls101-evaluation https://libraryguides.lanecc.edu/c.php?g=391374\&p=2658455 https://link.springer.com/chapter/10.1007/11912873_38 https://www.library.georgetown.edu/tutorials/researchguides/evaluating-internet-content https://www.library.kent.edu/criteria-evaluating-webresources

https://researcheracademy.elsevier.com/publicationprocess/open-science/publishing-open-access https://researcheracademy.elsevier.com/publicationprocess/open-science/open-science https://www.gartner.com/newsroom/id/3811367 https://www2.kenyon.edu/Depts/Religion/Fac/Adler/Evaluatin $\mathrm{gWebsites} 1 . \mathrm{htm}$

http://www.unesco.org/new/en/communication-andinformation/access-to-knowledge/open-educationalresources/what-are-open-educational-resources-oers/ 